\title{
FORBIDDEN WORDS: TABOO TEXTS IN POPULAR LITERATURE AND CINEMA
}

\author{
BY STEPHEN WHITTY $\dagger$ \\ stephenjwhitty@gmail.com
}

"A little knowledge is a dangerous thing."

That was said by Alexander Pope, one of the most knowledgeable of poets. Well, actually what he said was:

A little learning is a dangerous thing;

Drink deep, or taste not the Pierian spring:

There shallow draughts intoxicate the brain, And drinking largely sobers us again.

And clearly what he meant was that studying something only superficially may be worse than not studying it at all; that we can find ourselves "intoxicated" with one fact, rather than thinking clearly thanks to all of them.

What Pope was urging was true scholarship_-being well-read, well-rounded, and open to all ideas.

But the idea that ideas themselves can be dangerous- that true wisdom really comes from fervent faith, and that independent thought can lead you down a dangerous path-is an old one, and one that has sometimes led not to bibliophilia but bibliophobia, a fear that reading is perilous, particularly reading certain arcane and occult books.

There are, of course, such books. In fact the ongoing Rutgers Library exhibit, "Unheard of Curiosities," features a collection of volumes on what are called the "Occult and Esoteric Sciences." These are books on astrology, on necromancy, on prophecy, on all

† This paper is a version of a talk given by Stephen Whitty for the Twenty-eighth annual Louis Faugés Bishop III Lecture, which took place on April 7, 2014 at Rutgers University.

http://dx.doi.org/10.14713/irul.v67i0.1894

Journal of the Rutgers University Libraries, Volume 67, pp.1-18. 
the arts of the unseen. They include texts from ancient Egypt, from Dark Age wizards and from the Victorian aesthetes. They are books which were sought out for the powers-or shunned for the evilsthey were thought to contain.

And that deep-seated fear of knowledge, and the way it is encoded in the written word, is something that has never left us, and has encouraged an actual fear of learning - these days, "intellectual" seems to be almost as dirty a word as "elitist." Books continued to be burned, banned, and banished from libraries; newspapers remove or rewrite stories critical of special interests; dictators shut down websites and social media. And this is only because words have meaning, have power, have magic.

And sometimes, in cinema and literature, that magic is literal.

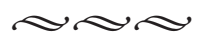

Of course, it wasn't just Pope who warned us about knowledge. From the beginning of history, self-education was often seen as a hazardous. In fact, in Genesis, it's said to be fatal. "But of the tree of knowledge of good and evil, thou shalt not eat. For in what day soever thou shalt eat of it, thou shalt die the death." It is actually the only command that God gives Adam and Eve, and they disobey it.

When Adam and Eve do eat from that tree, they do not "die the death" that day-unless you're speaking metaphorically about the death of eternal life, or just innocence itself. But their fate sets a dark precedent; a little knowledge is, indeed, not only a dangerous thing, but a forbidden, possibly even deadly one.

But the Bible warns us about the getting of too much knowledge. And the most important, and therefore dangerous, knowledge is contained in the Bible itself.

"Ignorance is bliss," wrote Thomas Gray, and that idea-or, at least, the suggestion that "ignorance is innocence" —is one which has never truly left Christianity, particularly traditional Roman Catholicism, whose leaders were not only vigilant in banning books and imprisoning their authors, but seemed to discourage the faithful from even reading the Bible.

It's a tradition which may seem odd to modern Christians and other believers, particularly Jews and Muslims who may devote their entire lives to studying, interpreting and debating holy texts, to whom words like "scholar" or phrases like "people of the Book" have a formidable and holy meaning. 
But I remember my Irish mother telling me that, while the nuns would drill students in the unwavering question-and-answer form of the catechism, they specifically discouraged their students from reading the Bible on their own. "You'll only misunderstand it," they told her.

The faithful, it seemed, were children who needed to be read to, particularly when it came to powerful books like this. Better the priest interpreted it for them, and dole out only what he thought they could possibly comprehend, and they could then learn by rote.

But while sacred texts contain special knowledge-prone, perhaps, to misinterpretation - they also hold power. Words have meaning, and magic.

You see this in the more mystical strains of Judaism, in which the Kabala is said to both contain the secrets of our universe and to be too dangerous for most people to even consider studying. Or in the ancient legend of the Golem, in which a rabbi brings a giant statue to life by inscribing a sacred word and placing it upon his chest. (It's a nice mirror image of the Chinese legend of the "hopping ghost" - a vampire-like creature who can only be killed by placing a piece of parchment with a sacred word on his chest.)

And you see it in Christianity too, which saw the Bible as a powerful tool for casting out demons, when used by the properly anointed (and, was sometimes, used in secret by the superstitious to gain advice or predict the future by opening the book at random and seeing what passage their finger fell upon).

No, written words have power, and the strongest depositories of that power are our religious texts, whatever that religion might be. And that's an ancient belief that remains part of our modern culture-and has driven two hundred years of terrifying popular fiction and a century of scary cinema. For the printed word, it seems, contains not only knowledge - that "dangerous thing" that Pope warns of-but also a key that can open doors which the truly God-fearing know should remain safely shut.

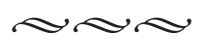

Of course, the very idea of popular literature was only possible once the populace was literate; it was not until the early nineteenth century, as a working class began to gain both the power of reading and the benefit of even some scant leisure time, that booksellers were able to hawk more than merely prayer books and scholarly tomes. 
Drawing on a tradition that went back to ghost stories told around the prehistoric fire, many of those new books were tales of terror, and a large number of them incorporated the very act of reading and writing into the narrative, as they presented their story in the form of diaries, letters or manuscripts, as in Wilkie Collins' The Moonstone (1868), Bram Stoker's Dracula (1897), and several of Edgar Allan Poe's short stories.

This literary device gave the most outrageous or supernatural events the veneer of truth, as the incidents were already contained in some sort of document. They also allowed the writer to reveal plot elements piecemeal, increasing not only the sense of mystery, but more directly linking audiences to the characters they were reading about. But even more importantly it actually dramatized literacy itself, and made us witnesses, practically participants, in the writing and reading of these stories.

These tales dramatized the saving power of words. In other tales, though, words themselves become the monster.

Inscriptions and translations, for example, figure heavily in the tales of M. R. James, a Cambridge scholar who titled his first Victorian-era collection Ghost Stories of an Antiquary (1904). Typically, James' hero is a vacationing professor who discovers an unusual book, or even a forgotten graveyard epitaph; just the mere act of noticing seems enough sometimes to give new life to a once dormant evil.

His masterful "Casting the Runes," set within the world of academia, is actually a literal publish-or-perish horror story; infuriated that his books on demonology aren't being respectfully reviewed in the proper journals, an amateur scholar and accomplished black magician then uses spells-written in runic characters on small slips of paper-to exact vengeance on his critics.

In case anyone here is tempted to follow his example, I'll point out that the last reviewer survives when he reverses the spell and the demon comes for the dissatisfied author, instead.

Even more famous was the same era's The King in Yellow, by Robert W. Chambers. The son of a wealthy Manhattan lawyer, Chambers went to art school, then spent the early 1890s in Paris, where he showed some of his work and became friendly with several members of the so-called Decadent Movement, then strong in France and England. Later in London, some of these menparticularly Aubrey Beardsley—would write for or illustrate a 
literary journal called The Yellow Book, which would inspire some to call the decade the "Yellow Nineties."

Chambers' The King in Yellow, published in 1895-and namechecked in the first season of the True Detective TV show (2014) - is a collection of nine loosely linked short stories; they include an anecdote of war, a prose poem, and some romantic sketches. The first half of the book, though, is dedicated to the macabre, and includes a story about a freakish man named Wildean ironic reference to Oscar, perhaps-who works as a mysterious "repairer of reputations." There's also a story about a devilish church organist and a walking, stalking corpse.

What links the disparate stories are vague references to a mysterious play called The King in Yellow. Chambers offers no details of any performances, or even more than a line or two from the play itself, but he warns that no one should ever read past the first act. To read the second is to go mad, or at least be possessed by some terrible compulsion, or victim to an awful fate. In fact, the only safe thing to do is shun the book entirely; it exerts such a hold that even those who toss it into the fire halfway through find themselves desperately dragging it out of the flames to continue reading.

Chambers' book was a best-seller-but the fictional The King in Yellow was only the first in what would soon become a vast library of, as Poe would say, "quaint and curious volumes of forgotten lore."

Dangerous ones, too. Of which the most dangerous would be the Necronomicon.

$$
\infty \times
$$

For the first half of the twentieth century, the dominant force in popular literature were "the pulps," so called because-unlike those magazines known inevitably as "the slicks" - they were printed on rough, newsprint-quality paper. Bearing lurid covers full of sex and violence, cramming a dozen or so stories in between soft covers for as little as a dime, they grew to encompass not only Wild West tales but stories of eroticism, adventure, horror and, most famously, hard-boiled private eyes.

Small enough to be crammed into a large pocketbook or roomy pair of overalls, they provided cheap, fast entertainment to working people happy to grab a free 10 or 15 minutes during a lunch break or on the trolley home; some magazines even printed an "Estimated Reading Time" at the top, so people knew if they'd have a chance to finish the story. Of course the reading time given 
was always generous; these were not magazines aimed at the highly educated.

Among the horror magazines, the leader was Weird Tales, and its most famous contributor was Howard Phillips (H. P.) Lovecraft, a tireless writer who turned out dozens of stories and cowrote, or rewrote, dozens more, mostly for as little as a penny a word. When he died, in 1937, all his books were out of print.

A character as eccentric as any of his excitable narrators, Lovecraft spent most of his life in Providence, Rhode Island, living with two elderly aunts, and keeping up a lively correspondence with many younger writers and fans he never met. He liked to think of himself as an elderly gentleman, called himself an "aged antiquarian" and often signed off his letters with such dusty locutions as "Your Most Obdt Servt."

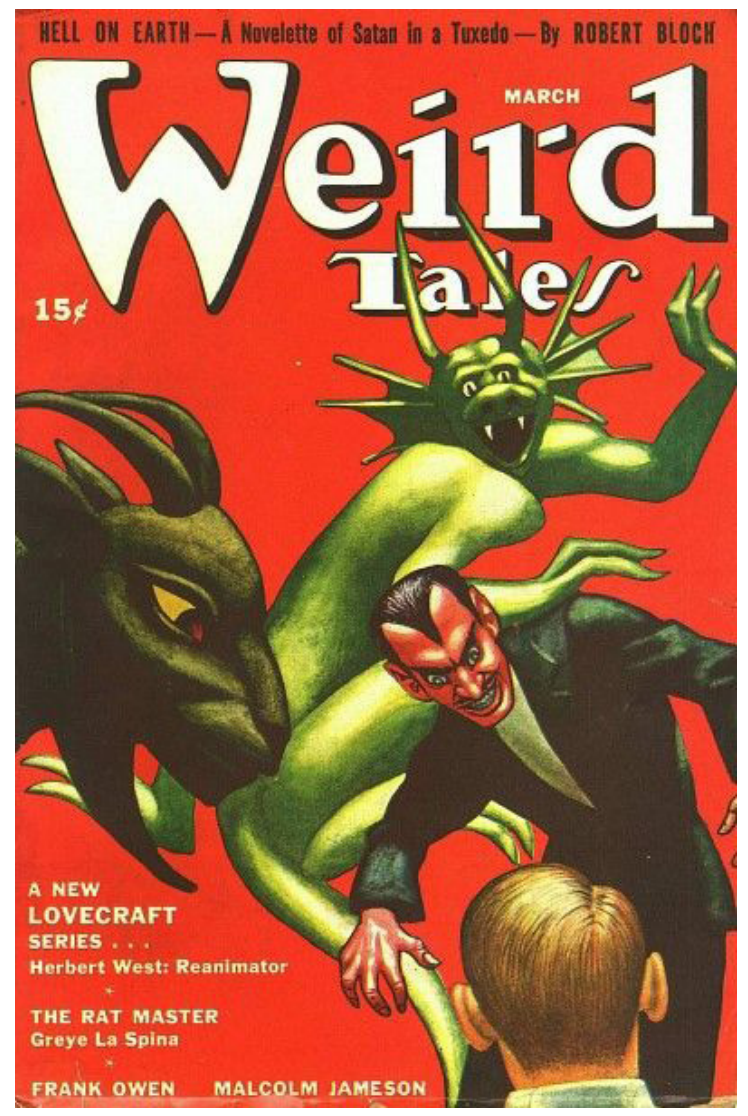

He was also

an appalling racist, whose bigotry extended not only to Jews and African-Americans-prejudices sadly common at the time even among many far more respected writers-but to Poles, Italians, Greeks and many other immigrant classes that he catalogued with careful, mounting disgust. It is, perhaps, no coincidence that many of his most famous tales — "The Dunwich Horror," (1929) and "The Shadow Over Innsmouth" (1936)—are about the product of unions between human beings and monstrous supernatural creatures; for Lovecraft, race-mixing was the ultimate horror. 
Of course, it was precisely the members of the immigrant working classes whom Lovecraft despised who were likely to be his readers. While many of his enthusiastic correspondents-the original "fanboys" - were Midwestern teens, the cheap, disposable magazines that Lovecraft wrote for sold largely in big cities to barely-literate adults-adults who, hardworking and often selftaught, were gradually pulling themselves up, and moving into mainstream society.

Perhaps that's why Lovecraft so often made books themselves the villain in his stories. Perhaps he also felt that a little knowledge was indeed a dangerous thing-because it was proving to be powerful enough to bring people out of the ghetto, and ever physically closer to his own white enclaves.

No one will ever be sure what Lovecraft's impulses were, of if he even understood them himself, but his stories regularly revolve around the dangers of reading forbidden texts. The best-known tales-a loose cycle later dubbed The Cthulhu Mythos-assumed there had been a monstrous battle for the cosmos eons ago. In the end, the Great Old Ones had been imprisoned, although not destroyed, by the Elder Gods-but they now waited for some unwary human to accidentally unlock the magical doors that bound them.

That was the myth that he founded his fiction on-alien intelligences, ambiguous texts, coded jargon. Today, of course, he might make it into an actual self-help religion and make millions.

But then it was merely a fantastic world of imprisoned gods and monsters-and the keys to their prison cells were the words contained in a single book, the Necronomicon, written by-as he was always referred to- "the mad Arab, Abdul Alhazared." The book was supposedly full of evil incantations, and fabulously rare.

Conveniently, though, there seemed to be one copy at the tiny, mythical Miskatonic State University in Arkham, Massachusetts, and it was in constant circulation.

It was Lovecraft's genius to give the book its own plausible history, often studded with the names of genuine scholars. According to various mentions in his stories, the Necronomicon was written in the eighth century, and translated into Greek in 950, when it was given its title by a scholar from Constantinople. It was banned in 1050 by Patriarch Michael, translated into Latin by Olaus Wormius in 1228, banned by Pope Gregory IX in 1232, but continued to appear in new editions in fifteenth-century Germany, sixteenth-century Italy and seventeenth-century Spain. 
With all that incredibly detailed and plausible provenance, is it any wonder that people still wander into bookstores and university libraries, looking for a copy?

It should be stressed that, whatever his personal prejudices and paranoia, Lovecraft wasn't delusional; he knew he was writing fiction. He was an amateur astronomer, and had read a bit about the occult, but as far as books on astrology and black magic went, he announced "in all truth they don't amount to much. That is why it's more fun to invent mythical works."

His large circle of friends-and imitators-joined in that fun, too. Their own Cthulhu Mythos stories function as a kind of bibliography, with each writer added new titles. Robert Bloch invented "De Vermis Mysteriis" by Ludvig Prinn. Clark Ashton Smith contributed "The Book of Eibon." Robert E. Howard suggested "Unaussprechlich Kulten" by Friedrich von Junzt. (Amusingly, Howard-whose German seemed to be rudimentarythought that translated as "Unspeakable Cults." Actually, an embarrassed friend told him, it meant "Unpronounceable Cults.")

These books were, of course, fictional too-and none had the carefully faked history of Lovecraft's Necronomicon. But once an author came up with a new title, other writers would incorporate it into their own stories. Horror fans, seeing the same foreign names and serious titles cropping up again and again in different tales, even different magazines, would be forgiven if they began to take all this as fact.

Yet whoever the writer, whatever the actual book encountered, the events that transpired in the story were almost always the same.

The tome is discovered in the library of some late, eccentric relative. The young heir begins to read it, stopping to puzzle over various handwritten annotations. Perhaps he consults his dead relative's diary, as well; perhaps he keeps his own journal, or sends letters to a friend. It's all in writing. But eventually, something which is not to be read-some word which is not to be spoken aloud-is. And this key of knowledge opens a horrible door, and something unspeakable-and at this point, Lovecraft in particular used to slip into vague adjectives and excitable italics-something of eldritch and unnamable horror slithers into the world.

Brought there by a book.

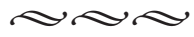

Outside the mythos, other writers spun stories about grimoires-books of magic spells or forbidden knowledge-or of volumes that were too dangerous for mortals to read. 
In Carl Jacobi's charmingly gaslit Revelations in Black (1947), for example, a young man poking through an antique store finds a small diary, handbound in black velvet and silver, called "Five Unicorns and a Pearl." Um, yes, the shopkeeper reluctantly explains-it was a journal kept by his poor brother after he went to the asylum, and it has no sense to it. It is-to invoke the title of a De Maupassant story- "The diary of a madman."

But the narrator is intrigued, and bullies the unwilling storeowner into letting him borrow the book. Reading it that night at home he finds it full of strange metaphors, yet oddly hypnotic. Returning to the store, he asks for any more writings by the madman, but the owner refuses. So the young man steals them, takes them home-and plunges deeper into fantastical fables of human animals and things that live by night.

Until he discovers the most horrifying thing of all: The author was not a hallucinating madman but merely a very careful reporter of things he saw-and things that still live.

Better still is the later "The Book" (1951) by Margaret Irwin, an author once celebrated for her popular historical fiction. In this modern story, a typical, respectably upper-class Londoner-father, husband, bowler-hatted banker-goes to look for something on his shelf and discovers a forgotten volume from a dead relative's library. Lovecraft and his coterie have already well prepared us for what happens next-there will be a hungry compulsion to read, a dulling of will power, the slow enabling of previously dormant evil forces.

Except in Irwin's story, the book isn't some dusty old copy of the Necronomicon, but another, unnamed book-and also, in its own way, a living thing. In fact, it is both a created work and its own creator, magically adding new lines, in Latin, to its text. At first they offer our hero tips on stocks, or ask for small rites to be performed. But then it demands he kill his own dog. And then it asks for the life of his child. He burns the book, in the end, but you fear it is he who will truly burn forever.

A similar, but more purely metaphoric tack is taken by Jorge Luis Borges (1975), in his short story "El Libro de Arena" or "The Book of Sand." In this, the protagonist-an avid collector-trades away an ancient Bible for a strange book in an unknown foreign language. Yet trying to read it, he discovers, is like being caught in a sandpit-the book somehow manages to make old pages disappear even as it adds new ones, and the more deeply the scholar immerses himself in it, the bigger the book gets. It is like drowning in words, 
and his only escape is to take the volume and hide it where no one will ever find it-in his country's National Archives.

The literary device of using journals, transcripts or letters to tell a story still continues; from the cult novel Ratman's Notebooks (1969) to Anne Rice's Interview with the Vampire (1976) to supernatural young adult fiction, many writers of horror stories use the form in order to establish a strong identification with the hero or heroine, and draw readers immediately and personally into their fantastic world.

But few authors are adding to Lovecraft's imaginary library, let alone coming up with their own grimoires. We do see short stories and novels about authors who are slipping into madness, or who can no longer tell the difference between fact and fiction, even authors forced to confront their own characters, now somehow made flesh and blood. These are in fact favorite themes of Stephen King-who, for one of the most successful authors of the last fifty years, certainly seems preoccupied with tortured writers.

Yet young heirs who, in going through their uncle's vast library, discover some dusty forbidden book; young men who take the wrong volume off a shelf in a second-hand bookstore and are introduced into a hidden world of beliefs-these characters are as out of place today as the heroes of M. R. James' famous ghost stories, antiquarians who, whilst taking a walking tour of quaint Cornish churches, would suddenly come across some curious stained-glass window or mysterious Latin epitaph above a crusader's tomb.

These heroes don't seem to exist anymore. Perhaps because those people who inspired them-the sudden inheritors of country homes, the pale habitués of downtown booksellers-don't seem to exist either. They are all part of our analog past—and while you could write a story about a haunted website, who on earth would want to read it?

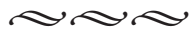

Popular cinema followed popular literature by a hundred years or so, with the first narrative films arriving at the turn of the twentieth century. But if the penny dreadful novels of Victorian England were aimed at a newly literate audience, the earliest films often counted illiterate workers among their patrons. And so, perhaps even more than in fantastic literature, in supernatural cinema the printed word was immediately seen as truly having magical powers, a formidable tool for evil, or good. 
Horror movies, as we know them today, began in different countries in different ways. In France, the genius George Méliès-as fictionalized in the recent Martin Scorsese movie, Hugo (2011)came to the fantastic by literal accident. Back when movies were often two-minute bits of mundane documentary, he had been filming the traffic in Paris, when the camera jammed for a moment; when he later had the film developed, he was astonished to see a hansom cab change into a hearse.

He had, fortuitously, discovered the first trick of stop-motion photography-and, as a former magician, he gleefully put it to work in a series of ground-breaking, yet still quaintly stagebound, movies about trips to the moon, the ocean depths, and the arctic wastes, every one full of Folies Bergère chorus girls and plywood monsters.

Simultaneously in West Orange, New Jersey, Thomas Edison and others were trying to gild their disreputable industry-at a time when movie theaters were rated just slightly above poolhallswith the shine of literary classics. So adaptations of such works as Frankenstein (1823) and Strange Case of Dr. Jekyll and Mr. Hyde (1886) were produced, monster stories that still had a moral at their heart, as well as some vaguely high-class pedigree.

In Germany, though, things soon took a different turn.

Drawing on a strong tradition of fairy tales and supernatural literature, early German films created a new kind of horror that both drew on medieval inspirations and added modern pessimism. A horrible fatalism stalked its entire cinema, whether it was the nightmare within a nightmare of the expressionistic The Cabinet of Dr. Caligari (1920) or the sudden lethal appearance of Jack the Ripper in Pandora's Box (1929).

German horror films also focused on the power of words.

Central to that was Paul Wegener, a former lawyer who-with The Student of Prague in 1913-became cinema's first horror star. Several of his subsequent films, including Alraune (1928) and an American movie, The Magician (1926) featured him as a scholar whose specialized knowledge led him into dangerous pursuits.

Words themselves are central to his films about the Golem. The art's first monster series began in 1915, and soon included a sequel and, in 1922, what we would now call a reboot; Wegener starred, co-wrote and co-directed these stories based on that legend of the sixteenth-century rabbi who created a giant clay statue; inscribing a special word on the statue (in some versions, the word for "truth," in others, one of the names of God) brings the creature 
to life- - life dedicated to walking the streets of the Prague ghetto, and protecting its citizens from anti-Semitic attacks.

Things go wrong, in what would turn out to be the prototype of every man-made monster film to follow; spurned by a woman, the golem runs amok. But what's interesting is that it's the word on the monster's chest, not the monster-maker, that holds the real power; once the word is removed, the creature collapses.

Words show up again in 1922's "Nosferatu," F. W. Murnau's copyright-be-damned adaptation of Dracula. In this telling of the story, personal letters and diaries not only figure, but incantations as well; the vampire is shown studying various arcane texts before the beginning of his attacks.

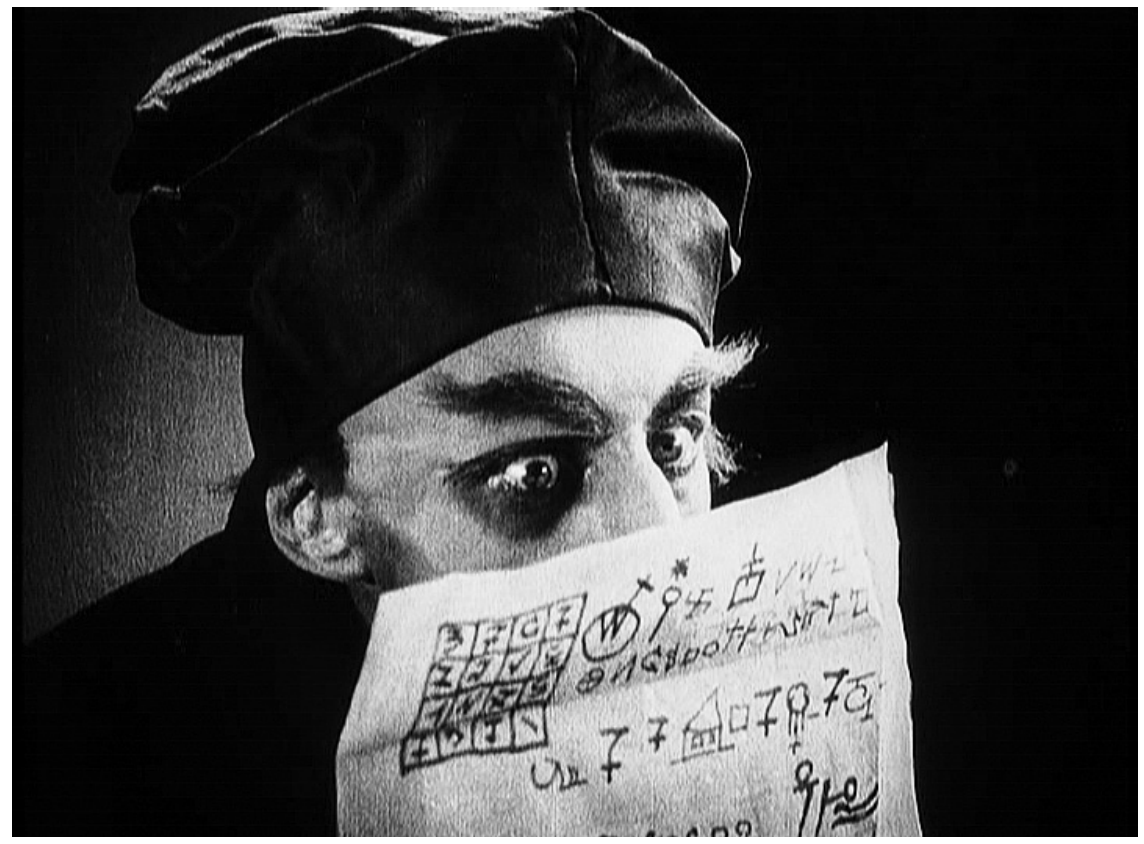

Actor Max Shrenk as Count Orlok viewing a mysterious, evil document in F. W. Murnau s film 1922 film Nosferatu.

Significantly, though, some of the characters we glimpse are clearly from the Hebrew alphabet. Like The Golem, the movie helps associate black magic and Judaism, and added to its other images and themes-the vampire's skullcap and hooked nose, the rats and disease he brings with him, his foul designs on virtuous German womanhood - turns what had been Stoker's nightmare about foreigners, lust, and venereal disease into a film full of specific 
Jewish stereotypes, anti-Semitic paranoia, and hateful metaphors.

And although that was probably not Wegener's intention with the Golem-his movies, after all, were about a magical creature who protected the Jewish community-it's difficult not to see the seeds of far greater German horrors to come in these monster movies about mysterious rabbis, foreign creatures and evil words. It may have been the Nazis who burned books in the public square, but the fear of certain dark and dangerous texts-that was a fire that had been kindled in that nation long before.

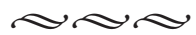

As the 1930s began, though, and America seized the leading role in the motion-picture industry, horror movies-and their stories of magical words and powerful books-took a different turn. And the guiding force turned out to be censorship.

When the movies first left New Jersey for California, Los Angeles was still the edge of the Wild West-and that attitude prevailed in its movies, when it came to censorship. There were no ratings, or even lists of what was or weren't allowed; early all-agesadmitted movies went out with gruesome violence, jokes about cocaine and flashes of nudity, and whether they were exhibited, banned outright, or edited on the spot with a pair of policeman's scissors depended entirely on the whims of state boards and community church groups.

It led to chaos, and-more worrisome from the studios point of view - talk of government regulation. So finally, in 1934, the moguls got together and wrote up a list of banned words, images, subjects, and even attitudes, and then set up an independent agency to pre-screen all movies, and enforce compliance.

Their new list of Don'ts was called the Production Code and among the many things it prohibited were any stories that might cause offense to any religion, or bring clergymen of any sort into disrepute or disrespect.

It was clearly, originally meant to avoid annoying the Catholics and conservative Protestants, who had always been Hollywood's greatest critics (to this day, the Church continues to publish reviews advising parishioners on which movies to avoid). But what it also effectively did was put an end to all stories about ghosts, witches, black masses, and many other supernatural topics.

Oh, vampires were still around (and still ran from the sign of the cross, although crucifixes themselves were rarely seen onscreen). 
And you could have Dr. Frankenstein create life (as long as he realized, in the end, that to do so was an offense against God, and worthy of the most drastic sort of punishment).

But you could not have a serious ghost story (because that implied that there was a life after death beyond that of the simple Sunday-school heaven or hell); you could not have a tale of witches or Satanists or zombies (because that asserted there were religions apart from mainstream Judeo-Christianity that were also valid and just as powerful).

So whereas the first, 1932 Mummy was brought to life by the reading of the sacred Egyptian Scroll of Thoth, in 1940s sequels, a brew of something called Tana leaves had to be the magic elixir, so that no pagan text was shown to have sole power; where the 1934 The Black Cat had Boris Karloff lisping Latin invocations before a group of Devil worshippers, his later villains would only quote chemical formulas and rely on dutiful, albeit hunchbacked assistants.

You could, if you wanted, still have ghosts or zombies-as long as you played them for laughs. But apart from a few rare examples-The Uninvited (1944), which told a classic ghost story, or The Seventh Victim (1943), which featured a strange modern cult-these sorts of monsters were effectively banned from Hollywood films as being too dangerously close to religion, or rather blasphemy. And with them went all the references to booksspellbooks and sacred texts and magic words-which were once part and parcel of those legends.

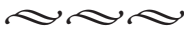

The censorship laws began to fall in the 1960s-attacked by changing mores but most of all attacked by competition from European films, which played urban arthouses uncut. Realizing they finally had more to lose from censorship than to gain, the studios banded together to revamp the motion picture code, now empowered not to cut material from films, but merely catalog what they contained and rate them accordingly.

This meant that not only that long forbidden words and images were now allowed-provided one paid the price of an " $\mathrm{M}$ " or " $\mathrm{R}$ " rating, and the corresponding cut in potential audience-but that topics once off-limits were now permitted. Dozens of onceverboten subjects-from kidnapping to drug addiction, interracial 
sex to sadism, homosexuality to abortion-now drew the attention of artists and, more often, crass exploiters.

It meant that stories about religion and the occult were now easier to do-and, once Rosemary's Baby (1968) turned a massive profit, extremely tempting, too.

With those movies, the idea of powerful magical texts again appeared on screen. This time, however, they tended to be the Bible-the Good Book becomes literally a good book, and something that could be brandished as a weapon against evil.

You see it first, perhaps, in vampire movies in which the Bible not only joins the cross as a holy shield of protection, but trumps it; in Dracula Has Risen from the Grave (1968), the monster is actually impaled on a cross, but only a Latin prayer can finish the job.

In The Exorcist (1973), words play an essential role, not only in the foul obscenities that the demon makes Regan use while possessed, but as a literal sign of her distress-while she sleeps, letters spelling out "Help me" rise up in welts on her bare skin. So it will be words that our heroes will try to use to save her-specifically those contained in the official rite of exorcism, known as "The Roman Ritual" which both priests will read in call-and-response fashion. Ultimately, it will be violence-and a stunning act of selfsacrifice-that saves the girl, but it is the priest's prayer books that serve as a constant weapon and which they cling too, even as they're drenched in pea-green vomit.

In other films, the Bible contains secret keys or explanations to the monsters being faced. The Omen (1976) began this popular subgenre of movies by quoting from the final book of the New Testament, the Book of Revelation. It's an almost willfully obscurantist text which some scholars read as an allegory about struggles among Jews, Christians, and Rome (with the number "666" being a coded reference to Nero), and which Thomas Jefferson called the ravings of a madman.

Other believers, though, see this book of the apocalypse-a word which literally means "the revealing" — as a prediction of the "end times" or "end of days," which will begin with the birth of the anti-Christ, proceed through great tribulations and fiery battles, and end with the destruction of the world and the second coming of the Messiah. It's very simply a factual guide-albeit a confusing oneon how to tell the End truly is near.

All this apparently not being dramatic enough for the makers of The Omen, they also added a bit of doggerel: 
When the Jews return to Zion

And a comet rips the sky

And the Holy Roman Empire rises

Then you and I must die

From the eternal sea he rises

Creating armies on either shore

Turning man against his brother

"Til man exists no more.

The poem is about as authentic a bit of Bible verse as "Even a man who is pure in heart..." is a true Gypsy legend; it owes more to paperback knockoffs of Nostradamus then to St. John, with its farfetched metaphors, self-fulfilling prophecies, and juvenile rhymes. But it seemed to lend enough verisimilitude to the movie to spawn several sequels and a remake, as well as inspire such other Book-of-Revelation B-movies as Prophecy (1979, which then spawned its own series), End of Days (1999) and The Seventh Sign (1988).

It's interesting to point out that these new, Bible-oriented horror stories first began to appear, not only as censorship faded, but as other new and sometimes frightening freedoms sprang up; they are essentially a conservative reaction to a radical time, with religion being presented as a powerful force for order. In The Exorcist-which is, on one level, about an adolescent girl's horrifying new sexuality-good is represented, essentially, by two older white men in uniform, wielding an official manual; in all the apocalyptic stories, the truth of our ultimate challenge, and how to meet it, is all there, in the sacred verses.

In these authoritarian stories, we are at war-and priests are our soldiers, and the Holy Bible their most sacred, and formidable, weapon.

\section{$\infty \times \infty$}

But pendulums swing, and just as these horror stories seemed to begin as a reaction against a chaotically liberated Americaoffering the promise, or at least potential, of blameless authority figures restoring order-other occult films acknowledged the chaos, even embraced it. And fittingly they turned, for plot and inspiration, not to the Good Book but the bad ones-dusty and devil-haunted books of forbidden knowledge. 
Once the old squeamishness about portraying black masses or pagan ceremonies started to fade in the 1960s, the stories of $\mathrm{H}$. P. Lovecraft began to come to the screen-although not quickly enough to help its author, who had died nearly penniless in 1937. Although often his works would get a modernization and a new title ("The Colour Out of Space" [1927] becoming Die, Monster, Die! [1965]) or a new title and an assist from a more bankable author (The Case of Charles Dexter Ward (1941) becoming The Haunted Palace (1963), supposedly inspired by a Poe poem), The Dunwich Horror (1970) brought back unadulterated Lovecraft, and the success of Re-Animator (1985) started a ghoulish spree that would include adaptations of From Beyond (1986), The Unnamable (1988), and Dagon (2001). Many would include references to his mad mystical-albeit mythic-library; one anthology film, Necronomicon, even named itself after the seminal work.

Perhaps the most successful Lovecraftian series of all, Sam Raimi's The Evil Dead (1981) franchise-growing finally to include the original film, two sequels, and a recent remake-introduced its own version of the Necronomicon, and spells which, when read aloud, brought the dead back to life. Unlike the dourly serious Lovecraft, however, the series had a mad sense of humor-in the second film, trying to elude his own severed but animated hand, the hero traps it under a wastepaper basket, weighted down with a copy of A Farewell to Arms. The third film, in fact, plays it all mostly for slapstick comedy, while the recent, unrelated, and self-knowingly parodistic The Cabin in the Woods (2012) reprises the idea one more time-again incorporating the Words Which You Must Not Read Aloud (which, nonetheless, poor unfortunates have been reading aloud, in one form or another, since the 1932 The Mummy).

The fact that most of these new horror films play their evermore-gory scares for dark comedy points to something else perhaps, and something not so funny-that in a world of vanishing libraries and disappointing bookstore sales, the very idea of a powerful printed volume of knowledge can no longer be taken seriously.

In Darren Aronofsky's Pi (1998), the Kabala is the sacred, dangerous book-but it is numbers, not words, that lead the hero toward madness. In Roman Polanski's The Ninth Gate (1999), the search for a rare and perhaps literally devilish tome is as much about the eccentric world of bibliophiles-and the eccentric performance of Johnny Depp-as it is about some dusty volume of forgotten lore. 
And the recent Ruby Sparks (2012) uses a favorite Stephen King device-the obsessed author whose characters come to stubbornly independent life-in service of a downbeat romance, which slowly turns into a meditation on how we can all create impossible images of our lovers, and then blame them for not living up to our fictions.

They are interesting works, but they are far different from what has come before. And as we hurtle on into the digital future, it's clear that we will see even fewer and fewer stories and movies about secret leather-bound books of forbidden knowledge not only because the idea of secret leather-bound books seems quaint, but because audiences will now longer be able to grasp the concept of forbidden knowledge.

How, in the world of the instantly gratifying Internet, can the Necronomicon not be online? Can a performance of The King in Yellow not be on YouTube? Can the Book of Thoth not have a spella-day account on Twitter? These are analog terrors, and they have no place in a digital age.

And yet, like Cthulhu himself, they live on, dreamingwaiting only for a discovery in a second-hand bookshop or a chance encounter on late-night television-to bring them back into shuddery existence. And back into our nightmares. 